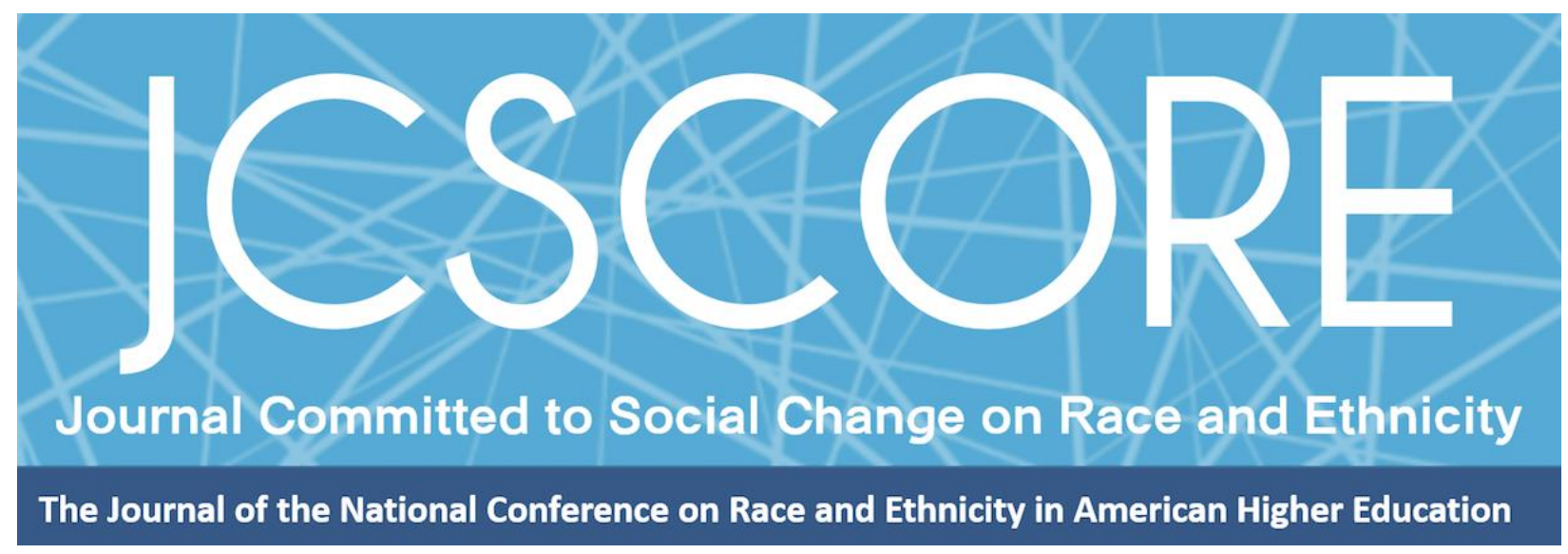

\title{
"WHERE WE ARE, RESISTANCE LIVES": BLACK WOMEN, SOCIAL MEDIA, AND EVERYDAY RESISTANCE IN HIGHER EDUCATION
}

Terah J. Stewart

lowa State University

Journal Committed to Social Change on Race and Ethnicity

Volume 5, Issue 2 | 2019

Copyright (C 2019 Board of Regents of The University of Oklahoma on behalf of the Southwest Center for Human Relations Studies.

Permission of the Publisher is required for resale or distribution and for all derivative works, including compilations and translations. Quoting small sections of text is allowed as long as there is appropriate attribution. 
Journal Committed to Social Change on Race and Ethnicity | Volume 5, Issue 2 | 2019

\title{
"Where We Are, Resistance Lives": Black Women, Social Media, and Everyday Resistance in Higher Education
}

\author{
Terah J. Stewart \\ lowa State University
}

The discourse about activism (and problematic conflations with resistance) typically offer comparisons to the 1960's Civil Rights Movement, examine first and second wave feminism, and situate apathy and fatigue as opposite from resistance. Using a qualitative research design (Merriam, 2009; 2002), Black feminist thought (Collins, 1990), and endarkened feminist epistemology (Dillard, 2006); this study examined the experience of 6 collegiate Black women and their resistance through engagement of the hashtag, \#BlackGirlMagic. Specifically, the inquiry explored how and why participants used the hashtag and investigated connections that give nuance to activism and resistance through community building, digital counterspace creation, and connections to higher education broadly. Findings include how participants conceptualize and define resistanceand how \#BlackGirlMagic serves as one way they can and do engage in resistance; and the author explores relevant implications for colleges and universities.

The social consciousness of college students is once again on the rise, and visible displays of activism command the collective attention of higher education scholars and administrators on college campuses (Jaschik, 2016). Historically, Black women have participated in activism, but their contributions to social movements are sometimes rendered invisible (Barnett, 1993). Recent studies of student activism have very few if any Black women as research participants, and few studies explore activism in terms of resistance. Research efforts that give nuance to activism and a sophisticated understanding of resistance will promote a better understanding of the experiences of Black women (Collins, 2002).

Critical scholarship such as critical race theory (Delgado \& Stefancic, 2012), critical tribal scholarship (Brayboy, 2005), and Black feminist thought (Collins, 2002) 
Journal Committed to Social Change on Race and Ethnicity | Volume 5, Issue 2 | 2019

each offer frameworks that suggest that research and practice must re-think and disrupt dominant narratives and ways of knowing in order to reveal how dominance negatively impacts the experiences of subjugated people. Expanding the definition of activism and what is recognized as activism disrupts a cycle that renders certain types of resistance invisible. If definitions of activism are limited to only public and visible displays of action and organizing, scholars and practitioners risk potentially ignoring the needs of students who resist through non-traditional means. Educators must better understand how Black women engage in activism and/or resistance on college campuses to learn if there are meaningful and intentional ways university administrators can support them.

During my time as a student affairs educator, I often observed marginalized students communicate they were experiencing hostile campus environments. Most of their communication did not include marches, protests, and sit-ins, but instead they had conversations online, held town hall meetings, and sent emails to leaders within the institution. Those experiences pushed me to consider who was missing from the activism discourse, what exactly is resistance, and whose work I was privileging as true activism. To this end, as an administrator I wanted to be sure I was not overlooking potential student concerns because their resistance was not public and obvious to me.

The intent of this inquiry is to explore how Black women on college campuses engage in everyday resistance via Twitter. I define everyday resistance as cultural resistance operationalized as non-cooperation with dominant societal narratives (Johansson \& Vinthagen, 2016). Next, I will describe the conceptual frame that informed this study, along with a positionality statement and methodology. Finally, I offer my findings related to this inquiry, their implications, and directions for future research. 
Journal Committed to Social Change on Race and Ethnicity | Volume 5, Issue 2 | 2019

\section{Conceptual Framework}

I ground this study in Black women's ways of knowing in tandem with resistance studies philosophies. Here I offer a brief overview of relevant literature related to digital activism and resistance. Finally, I offer Black feminist thought as the theoretical framework that undergirds the literature and analysis process. The relevant literature and theoretical framework come together to form the conceptual framework of this study.

\section{Black Women and Digital Activism}

Black women engage in forms of everyday resistance and counterspace creation through engagement on social media and other online spaces (Glenn, 2015; Williams, 2015; Yang, 2016). While some of these digital spaces are celebratory in nature, many are spaces for critical dialogue about important issues relating to their experiences (Towns, 2016). Engagement with a digital platform is possibly one place where Black women are finding community and support on their college campuses (Domingue, 2015).

Williams (2015) posits that digital activism positions Black women to share information and engage in action that advocates for their needs and experiences. Furthermore, Williams credits hashtags with the unique ability to focus attention on Black women's issues when mainstream media continues to ignore them, as they have for centuries. Hashtags, specifically on Twitter, are an important tool for Black women so they can connect with each other in real-time to engage about their issues and concerns that center their experiences and ways of knowing (Towns, 2016). 
Journal Committed to Social Change on Race and Ethnicity | Volume 5, Issue 2 | 2019

\section{Resistance}

Everyday resistance is a routine action and may not be politically aligned or formalized (Johansson \& Vinthagen, 2016). A key component of everyday resistance is that actions by individuals and groups can often be undetected as resistance or made to be invisible by society. Many studies engage student activism from a traditional perspective (marches, protests, sit-ins). A traditional view relates to actions that include public organizing and confrontation toward interrupting dominant power and the social order (Johansson \& Vinthagen, 2016). In contrast, everyday resistance can be a form of activism that students engage with as a means of self-care, survival, and creating counterspace (Case \& Hunter, 2012).

Resistance can also be everyday acts of eluding the consequences of oppression (Butz \& Ripmeester, 1999), which could include several different direct and non-direct actions such as engaging on Twitter using hashtags. Philosophically inherent in resistance perspectives is the recognition of power as a construct and legitimate force in the lives of marginalized people. In this framework, everyday resistance is legitimized and allows more nuance which is necessary for examining relationships between aspects of resistance and power (Scott, 1990).

Reframing activism is important because it invites more range and depth for what type of behaviors and engagement are recognized as resistance and activism. This consideration is important because, if acknowledgements of resistance are limited to traditional manifestations of activist praxis, scholars and practitioners might be unintentionally privileging certain student issues over others. Furthermore, there is the potential that campuses will miss the totality of students in campus communities who 
Journal Committed to Social Change on Race and Ethnicity | Volume 5, Issue 2 | 2019

need support if the process is to wait for marches, protests and sit-ins (Stewart \& Williams, 2019).

\section{Black Feminist Thought}

Black feminism is a body of thought that centers the lived experiences of Black women and serves to illuminate the complexities and fullness of Black womanhood (Collins, 1990). Scholars of the black feminist tradition suggest that the experiences of Black women vary greatly from those of White women/women of color and Black men. To this end, an understanding of racial and gender oppression is required to examine the experiences of Black women (Howard-Hamilton, 2003).

Black Feminist Thought offers clear considerations relating to Black women's activism. Collins (2002) offers that research may be more practical to understand Black women's activism "less by the ideological content of Black women's belief system ... and more by Black women's collective actions within everyday life that challenge domination in these multifaceted domains" (p. 203). Given that dominant notions of activism do not always include room for experiences by those with multiple subjugated identities, Collins offers context for Black women's activism that expands the depth of what type of action should be considered legitimate. Furthermore, Collins argues that through their work, Black women have created an activist tradition that legitimizes their existence as resistance. They create "Black female spheres of influence that resist oppressive structures by undermining them... they embrace a form of identity politics, a worldview that sees lived Black experiences as important to creating a critical Black consciousness" (Collins, 2002, p. 204). 
Journal Committed to Social Change on Race and Ethnicity | Volume 5, Issue 2 | 2019

What would it mean to resist traditional definitions of activism which may marginalize narratives and experiences of Black women? According to Collins, there are situations where Black women are neither interested or able to participate in direct or public confrontations, and there are dimensions of Black women's activism that more closely resemble undermining or resistance (Collins, 2002). Given that traditional activism has not always been ideal or possible for Black women, Black feminism encourages scholars and activists to dig deeper and uncover how resistance manifests in a variety of ways. In this sense, this study explored everyday actions (such as engagement on social media) as resistance, and resistance as potential activism as dictated by Black women themselves. Collins (2002) argues that centering Black feminism is more inclusive for Black women's current and future action to be recognized as activism.

\section{Researcher Positionality}

As my proposed research study explores Black women engaging in resistance through hashtags and counterspace creation, it is important that I address my own worldviews and experiences as they may relate to my interpretation of the data and how I guided the study. First and foremost, I recognize my own privileged identities including that I am a cis-man and "traditionally" educated. The more important of these considerations is that I am a cis-man studying Black women. I also identify as queer and, while I often find community with Black women, it however does not change that I am not a woman. Given this reality, I often wrestle with the potential implications of me "speaking for them" through my research. I want to ensure I do not engage in a paternalistic manner and also maintain a commitment to centering Black women's 
Journal Committed to Social Change on Race and Ethnicity | Volume 5, Issue 2 | 2019

voices who are frequently ignored. In terms of other salient social identities, I identify as Black, generationally poor, and fat-bodied. Each of these identities have histories and legacies of experiencing violence through the system of dominance that plagues society and, as such, positions me to attend acutely to dynamics of power.

Lastly, I identify as a former student activist and have engaged with many student activists through the years; I was heavily involved in campus politics and change as an undergraduate student. That experience allowed me to witness when and how resistance is implemented and to connect on an emotional level with resistance as a struggle. Being a former student activist positions me to understand many ways resistance is precipitated that do not include marches, protests, and sit-ins. Most recently, I served as an Assistant Director of a Multicultural Center at a large public institution in the Midwest where I was charged to oversee a team of staff that support marginalized communities on campus, which often meant we were tasked with trying to balance support for their concerns and our roles as agents of the institution.

\section{Methodology}

For this study, I employed a qualitative research design (Merriam, 2002; 2009) paired with an endarkened feminist epistemological framework (Dillard, 2006). Researchers have used qualitative research designs in psychological research (Perry, Kostere, \& Kostere, 2015), nursing research (Dames, 2018), and education (Merriam, 2002). A qualitative design is useful for researchers interested in "(1) how people interpret their experiences, (2) how they construct their worlds, and (3) what meaning they attribute to their experiences. The overall purpose is to understand how people make sense of their lives and their experiences" (Merriam, 2009, p. 23). My decision to 
Journal Committed to Social Change on Race and Ethnicity | Volume 5, Issue 2 | 2019

utilize a qualitative research design was based on my desire to understand how Black women make sense of their experience engaging in digital communities and what connections exist for them related to resistance. Further, my point of entry to this study was to explore the \#BlackGirlMagic hashtag on twitter, but felt it was irresponsible to do so without speaking to the Black women who engage, grow, and develop that space. Given the lack of a developed methodology that would incorporate an internet-related ethnography component and a narrative inquiry component together, a qualitative design seemed most appropriate to accommodate the critical flexibility I needed.

Endarkened feminist epistemology (Dillard, 2006) centers the experiences of Black women and engages research that aims to re-center conceptions of knowledge (Dillard, 2008). Endarkened feminist epistemology reinforces and legitimizes life experiences as a primary way Black women make meaning of the world. An endarkened feminist epistemology requires situating research as a responsibility obligated to the people and communities that are engaged in the inquiry, which in this case are Black women (Dillard, 2008). The research must focus on healing and humanizing Black ways of knowing.

An integral component to engaging endarkened feminist epistemology as part of the framework and methodology includes utilizing life notes to help reveal nuance within the experiences of Black women. Through this study, I consider tweets and hashtags as life notes or specialized bodies of knowledge (Dillard, 2008). Life notes can be considered a tool that a researcher can use to understand the unique experiences of Black women and engage those experiences as truth (Dillard, 2006). Life notes function to illuminate Black feminist ways of knowing "in moments of reflection, relation, and 
Journal Committed to Social Change on Race and Ethnicity | Volume 5, Issue 2 | 2019

resistance" (p.6) that show who Black women are when they are their most authentic self.

\section{Data Collection}

To inform the interview protocol, I examined the hashtag \#BlackGirlMagic (@thepbg, 2017). I randomly selected a 3-day window and collected tweets from any public profile that contained the hashtag. The tweets were selected automatically with a google chrome extension called Twitter Archiver, which will identify tweets with the parameters I outlined (\#BlackGirlMagic and a three-day period) and collect them in a spreadsheet. I selected this hashtag because it is one of the most popular tags that include both Black and girl/woman in its name.

The purpose of collecting the tweets was so that I could gain an initial understanding of \#BlackGirlMagic as a counterspace which would more powerfully inform the interview protocol. To prepare for the interviews, I utilized preliminary coded tweet data as the life notes of the study. I utilized Goodman and Light's (2016) method for analyzing tweet data that included coding a tweet based on what is pulled into the coding sheet only: the text of the tweet and embedded media. If the content of the tweet was difficult to understand without additional context, then I clicked on the url of the tweet to review the original tweet as it appeared on twitter. That step allowed me to understand any relevant "conversations," "threads," "memes," and other content attached to the selected tweet and hashtag. Where there was still difficulty understanding the meaning or purpose of the tweet I clicked on any additional links or content. 
Journal Committed to Social Change on Race and Ethnicity | Volume 5, Issue 2 | 2019

From the tweet analysis, I learned that \#BlackGirlMagic seemed to be mostly about celebration of Black women's accomplishments and achievements. The tweets of the community were utilized to support and uplift other black women. Tweets were also used to highlight Black women owned business and services and to focus on Black women's labor. Additionally, the hashtag was used to highlight the action of Black women also making a difference in the world, specifically those engaged in resistance, ranging from the political (Maxine Waters) to social/cultural (@CharleneCac). This information was used to develop the interview protocol to determine if participants agreed with my understanding and observations of the digital part of the community.

A total of six interviews were conducted in-person or over skype and lasted 90 minutes each. The interviews occurred between June 2017 and September 2017. Interviews were audio recorded and then transcribed for analysis purposes. I used a semi-structured interview technique that included questions related to \#BlackGirlMagic, Twitter, resistance, and identity, and that was salience to their student realities. Some questions included: How have you used \#BlackGirlMagic on Twitter? Why do you engage the hashtag in that way? What is your understanding of resistance? What is your understanding of activism? Do you consider yourself an activist? In what ways does your engagement with \#BlackGirlMagic inform your campus experience?

\section{Participants and Setting}

I recruited participants from a large historically white university in the southwest of the United States. I advertised my study through social media outlets by posting a digital flier. I posted on Twitter, Facebook, and through university outlets including the Multicultural Office, NPHC email list, student organizations related to Black women and 
Journal Committed to Social Change on Race and Ethnicity | Volume 5, Issue 2 | 2019

other listservs and forums. African American students make up approximately $7.7 \%$ of the total student population at the institution.

Table 1. Participant Demographics

\begin{tabular}{|c|c|c|c|c|}
\hline Name & $\begin{array}{l}\text { Sexual } \\
\text { Identity }\end{array}$ & Status & Major & $\begin{array}{l}\text { Other Salient } \\
\text { Identities }\end{array}$ \\
\hline Alana & Heterosexual & $\begin{array}{l}\text { Recent Graduate } \\
\text { (MA) }\end{array}$ & $\begin{array}{c}\text { Public } \\
\text { Administration }\end{array}$ & Christian \\
\hline Lisa & Heterosexual & $\begin{array}{c}\text { 4th Year } \\
\text { Undergraduate }\end{array}$ & Public Relations & Christian \\
\hline Mary & Heterosexual & $\begin{array}{l}\text { Recent Graduate } \\
\text { (BS) }\end{array}$ & Biological Science & $\begin{array}{l}\text { First-Gen } \\
\text { Christian }\end{array}$ \\
\hline $\begin{array}{l}\text { Saraphin } \\
\mathrm{a}\end{array}$ & Demisexual & Doctoral Student & Biomedical Science & Womanist \\
\hline Terri & Queer & $\begin{array}{c}\text { 3rd Year } \\
\text { Undergraduate }\end{array}$ & $\begin{array}{c}\text { Fashion } \\
\text { Merchandising }\end{array}$ & $\begin{array}{c}\text { Agnostic } \\
\text { Environmentalist }\end{array}$ \\
\hline Trina & Bi/Fluid & Doctoral Student & Education & $\begin{array}{l}\text { First-Gen/Raging } \\
\text { Feminist Bitch [sic] }\end{array}$ \\
\hline
\end{tabular}

Participants for the interviews were Black women who self-identified as having posted content on Twitter with the \#BlackGirlMagic hashtag. There was a total of six participants, three undergraduate and three graduate students (review Table 1). All women were in a degree-seeking program, two participants were recent graduates, one year or less from having attended the institution. Three participants identified as heterosexual, one as queer, one as bi/fluid, and one as demisexual. Most participants identified with a lower-middle class socioeconomic status, but some also identified as being generationally poor. Participants describe generational poverty as a designation that acknowledges how their families have a history of living in poverty, even though they and their families may currently be working class. Economic status was 
Journal Committed to Social Change on Race and Ethnicity | Volume 5, Issue 2 | 2019

complicated because the participants were constantly negotiating their own movement across different class statuses with some of their families remaining static. One participant offered that for her the term also means, that while she may not be living in poverty her immediate family is and being generationally poor means she is unable to help them currently and she may never be able to. Beyond these identities these women were quite different with salient identities that included agnostic, Christian, womanist, environmentalist, first-generation, and raging feminist bitch [sic].

\section{Data Analysis}

Black feminist thought remained the framework through which I conducted data analysis. Throughout the coding and theming process, I referred to Collins' discussion of Black women's activism, specifically the first dimension that she discussed to interpret and handle the data:

This dimension may not directly challenge oppressive structures because, in many cases, direct confrontation is neither preferred nor possible. Instead, women craft Black female spheres of influence that resist oppressive structures by undermining them... Recognizing that the path to individual and collective empowerment lies in the power of a free mind, these spheres of influence often rely on crafting independent and oppositional identities for African-American women. (Collins, 2002, p. 204)

In this way, I engaged the data through a lens that allowed me to notice when and how these participants were engaged in resistance through undermining a dominant narrative. I also worked to notice when participants were engaged in the process of crafting what Collins' refers to as "independent and oppositional identities" in an effort to develop their "free mind" perhaps contrary to what the social media or college environment might say to or about them. 
Journal Committed to Social Change on Race and Ethnicity | Volume 5, Issue 2 | 2019

I completed a three-cycle coding process for this study (Saldaña, 2009). The first round included using a descriptive coding method and manually coding each participant transcript to include an overarching research purpose tag and then the selected code. A passage of text would either be tagged with BGM (for BlackGirlMagic), Tw (for Twitter), Res (for Resistance) or Hot for intriguing data that did not fit with the other tags. Codes included BGM - as a pathway to activism, Res - as existence in the academy, Twitter means to share voice, Hot - money for Black women's labor. Connecting back to Black feminist thought, I coded data based on any action or language that overtly or covertly signaled undermining or resistance. For example, when participants shared they believed their literal presence in the academy was resistance, I connected that to their literal presence undermining dominance specifically within their higher education context.

The second round of coding included grouping data by research purpose category and then developing a code map that included collapsing codes into larger categories. Once that was completed, I combined similar and adjacent codes. For example, the codes BGM-a good feeling, BGM-pride, BGM-motivator/motivation, BGMwe poppin, were all collapsed into the "Belief in Self" code. The previous mentioned process elicited a total of ten codes or categories across all the data. The third round included recoding based on the ten categories and then one round of theming the data which elicited three major themes.

I ensured trustworthiness through triangulation, participant debrief, as well as peer debriefing and review. I achieved triangulation through utilizing tweet data to develop the interview protocol as well as comparing the narratives of participants with 
Journal Committed to Social Change on Race and Ethnicity | Volume 5, Issue 2 | 2019

the emerged codes from the tweets. I asked participants their opinions of those codes/data to ensure consistency. Peer debrief and review included multiple conversations between me and colleagues in my program of study. A faculty member and doctoral level scholar-practitioner who both engage research specifically by and about Black women reviewed my coded data and my findings to ensure clarity of the analysis process. Finally, I presented my participants with the findings to understand the degree to which I accurately captured their stories, sentiments, and feelings in my analysis and documentation of the data through this study.

\section{Findings}

Through their stories, participants shared in vivid detail the ways that \#BlackGirlMagic show(s/ed) up in their lives in meaningful and intentional ways. I began this work by inquiring about how Black women on a college campus engage in everyday resistance through Twitter; however, the findings from the study reveal a deeper meaning.

Three major themes emerged from the data analysis process. First, participants communicate in very clear terms that their existing in the world and social media is a form of resistance. The women define what resistance means to them, and they nuance the differences between resistance as being and resistance as doing. Secondly, participants highlight that for them, \#BlackGirlMagic is a war cry through which they can build a capacity for their belief in self, develop community, and use their engagement as tool for many purposes in their daily lives. The third theme relates to Black women and their realities as students in higher education. The participants remind us that when 
Journal Committed to Social Change on Race and Ethnicity | Volume 5, Issue 2 | 2019

Black women thrive, institutions thrive; and it behooves educational institutions to position these Black women to be successful in every way possible.

\section{Existence as Resistance}

"I think my resistance comes from just existing in this white space, to be here unapologetically."- Terri

Resistance as Being. Participants revealed that for them, in the places and spaces where they take up space, resistance lives. They push against the notion of conflating activism and resistance and tease out further the differences within how resistance is understood both online and offline, making clear that existence is resistance. For example, Trina shared that her resistance manifests through her identity as a doctoral student. Recognizing that although there is some privilege in having the opportunity to pursue advanced education, her identity as a Black woman allows her to push back against oppressive structures:

I feel my work (scholarship) around resistance, and, my literal being in the academy as a form of resistance. I think of that as being integral to who I am, because I owe it to those that supports me, that help create this space for me to get here.

Existence on college and university campuses was a constant point of reference for these women. Saraphina repeatedly spoke about her experience in the sciences and what it meant to be the only Black woman in her program and disrupting dominant understanding about Black women and their experiences. She described resistance as:

I think just being transparent about what it is to be a black person in science or America within my friend group I am very clear about that, and I make sure to have those conversations even though they're uncomfortable. And for me that is resistance because I think, especially liberal people have tendency to move toward colorblindness, and so they see my blackness but they don't want to talk about it because they believe that makes them racist or that it's taboo. 
Journal Committed to Social Change on Race and Ethnicity | Volume 5, Issue 2 | 2019

As a theme, existence as resistance also included being their authentic selves inside of dominant spaces and dominant expectations as well as inside of their own communities. For example, Terri shared that resistance meant simply, being herself:

I feel like if I had to be put into this mold of that perfect Black girl who tried to fit in with these white people, that would not be resistance, that would just be trying to make myself palatable for them.

Resistance as Doing. Beyond existence in the academy, existence on social media and engagement in digital spaces was also named as a site of resistance. Participants share that wherever they are, resistance is there and that includes on Twitter. Engaging \#BlackGirlMagic and other online communities of Black women, participants declare is a part of their resistance. Saraphina states:

I think because we have to make those spaces for ourselves, it becomes resistance. I don't think those spaces per se are afforded to us in most places. Most places are not conscious that those spaces need to be there, therefore they don't use their resources to make those spaces and so sister circles, \#BlackGirlMagic, online Black women communities are made because we see the need for them and they are made by us. Usually they are not made by anybody else, and so I think that is resistance because that's saying, "you might be ignoring me but we're not ignoring us, so we're gonna do it ourselves."

As the study progressed, it was clear that the meaning these women ascribe to \#BlackGirlMagic transcended the literal hashtag and media shared on the tweets that contained the messages. \#BlackGirlMagic also identifies the community/circle of Black women that they engage with online. Engaging this community is sometimes used as a buffer for the violence and trauma often present in the world and in conversations on the site of study, Twitter. Alana shares:

I might see a news report or something, another incident with the police, another current presidential administration... whatever. I might see some crazy stuff that's happening here (the United States), but then I see a series of tweets from women, and we're celebrating each other, we're sharing pictures, we're liking 
Journal Committed to Social Change on Race and Ethnicity | Volume 5, Issue 2 | 2019

stuff. I definitely feel like it's a counter space, and then it ends up a form of resistance and because I would retweet those things, because I reply and say that I'm also celebrating those people, I am active in that resistance space.

In this way, engaging in this space can be a form of resistance through focusing on and celebrating joy amid trauma and confusion. \#BlackGirlMagic is a space for these women that serves as a buffer to the many microaggressions and macroaggressions they experience every day. Mary conveyed this sentiment of \#BlackGirlMagic's celebration of accomplishments as everyday resistancethat disrupting dominant narratives/expectations:

If I told you, "I am 20 whatever years old, and I just finished writing a dissertation on $\mathrm{X}, \mathrm{Y}$, and Z," you'll be like, "Oh, excuse me." In that accomplishment, and in celebration of that accomplishment, it can be resistant, because it's literally taking what people don't see as a common norm and elevating it so everybody can see it. There are just so many things that we do on a day to day that resist. Even so much saying, "I don't agree with that," is a form of resistance. If I see something online, I'm like, "Yo, I don't like that. I don't agree with it." See it on the news, "I don't like it." That, to me, is also resistance.

Some participants in the study also shared significant stories of their time engaging activism which for them was different from resistance. Types of engagement included marches, protests, mentoring, and financial support/donation to people and causes they care about. Some participants did not identify with activism at all, but each of them in some way identified as having engaged in resistance. Resistance for them was defined as pushback in any form, disrupting the status quo, and redirecting the dominant narrative as it pertained to their experiences, identities and personhood. Alana shared the following:

I think in action, resistance looks like dispelling myths or narrative of stereotypes or shining light to uplift others. Particularly marginalized groups. So, resistance looks like having a graduate degree from a historically white institution. Multiple, because I have three degrees now, from a historically white institution. I think, 
Journal Committed to Social Change on Race and Ethnicity | Volume 5, Issue 2 | 2019

yeah, me, personally, is that the academic accomplishments I have serve as a form of resistance.

As evidenced by participant stories, resistance was a simple as their presence on campus because of an environment that was not always conducive to their well-being. The women offer nuance to resistance to include being and doing. Resistance as doing highlights that the women understand the importance of direct action; however, they revealed that action is not required for resistance to exist. Their labor toward educating people about their experiences and the placement of their physical bodies as disruption is a radical notion that warrants further exploration and engagement by educators.

\section{\#BlackGirlMagic: A War Cry}

"Black girl magic, it's powerful, it's strong, it's beautiful, it is the reason we are who we are, it is strength, it's resilient, it is literally looking at the face of odds and defying them. It's more like a war cry." - Mary

Participants reveal that \#BlackGirlMagic has numerous uses for them in their daily lives. For the purposes of study, the \#BlackGirlMagic hashtag was selected given its wide use by Black women and their supporters. \#BlackGirlMagic not only included the hashtag but the personification of the women themselves: it is a digital space as well as a physical one. \#BlackGirlMagic permeates multiple areas of their lives and helps cultivate a sense of support, pride, and love. Lisa explains,

\#BlackGirlMagic is really important to me because I feel like if we don't uplift each other, who else is going to do it? Especially in today's society. White women and other races are always valued and talked about. They're always featured in movies. You don't always see people that look like you. When you do see these people that are doing amazing things out there and that are glowing and they're Black women, that's just important to have that representation and to show others, "Yeah, you can do something amazing. We're going to uplift you for it even if no one else does." That's just why it's is so important for me. 
Journal Committed to Social Change on Race and Ethnicity | Volume 5, Issue 2 | 2019

Participants indicate they find support in other women and strength to endure the pressures of systemic oppression through the \#BlackGirlMagic community both online and offline. In some ways, they only seem to find this support, from other Black Women. Mary shared the following:

One of the biggest things for me that I kind of realized while at [institution]. You don't get that type of love, that type of Black girl magic love from white people. I mean, they'll be like, "I like your hair," but that's pretty much the extent of which it goes. You know, Black women have another superpower of hyping each other up. I mean, hair, makeup, clothes, dancing shoes. There's this safe space between us. I think that really transformed my time at [institution].

Lisa also shared these sentiments,

I just like the fact that it's exclusive almost. That belongs to us. If someone else that wasn't a Black woman used it, it doesn't have the same effect. It's just like that's exclusive to us. Just like the whole magic part, it just feels like no one else can touch that. I just like the saying, the phrase. It just feels really uplifting.

Participants shared that \#BlackGirlMagic is a tool to highlight accomplishments for other

Black women to look up to, to serve as a buffer against the multiple ways Black women experience violence in the academy, in the world, and especially online. Trina offered,

And for me it was about Black women are doing all of these things, in spite of the system of oppression that plagues our society, that plagues our workplaces, that plagues our culture, we're still out here doing really good work and here are all the representations of it. So, for me, it was a way to celebrate all that Black women are doing, and then to give other people a reason to look up to whatever it is I'm celebrating or posting about.

Participants also conveyed the importance of why \#BlackGirlMagic framing is important to highlight accomplishments, achievement, and to find community. Mary offered the importance of this framing by highlighting the unique challenge of being both Black and a woman and the way oppression shows up at the nexus of those identity experiences:

As an African American woman or as a Black woman, she automatically would have two things going against her. She's a woman and she's a minority. That's already double the trouble.... I think it's always super important to recognize the 
Journal Committed to Social Change on Race and Ethnicity | Volume 5, Issue 2 | 2019

challenges people face, even to get to the same point. If a Black woman reaches the same level as a white man, both accomplishments are great. I'm not going to take away from the white man, but I am going to go the extra step to recognize the Black woman for all that she's done and all that she's had to go through to get to that point.

Finally, participants identify several utilities for \#BlackGirlMagic, highlights include using the hashtag and community as a tool for representation, a pathway to activism, a narrative reframe and even a form of public education. Saraphina shared that, as a scientist, she has a close approximation to whiteness almost daily, as such:

By me outwardly celebrating \#BlackGirlMagic, outwardly celebrating my blackness that gives people exposure to that. And it's kind of been my platform, not only online but just in life, l'm very vocal about Black issues and Black conversations with my white friends, not because I want acceptance but so they understand what's happening; and they kind of get a different exposure that they might not get otherwise.

Throughout the process of exploring the stories, \#BlackGirlMagic was proven to be a multidimensional site of pride, love, resistance, and utility. \#BlackGirlMagic not only included social media engagement but also the sister circles and communities of Black women that these women have cultivated as a means of support to move boldly through their daily lives. \#BlackGirlMagic is indeed a war cry, one that inspires, protects, refuels and rejuvenates these women.

\section{When Black Women Thrive, Institutions Thrive}

"\#BlackGirIMagic is going to happen anyway, institutions need to get with that happening, they need to provide the space and resources needed to help those women thrive to be the best they can at their institution. Because when Black women thrive, then the institution thrives." - Alana

Each of these women shared identities as Black women; the other aspect they had in common was that each of them was a college student, and each shared specific ways they saw the relevance of \#BlackGirlMagic to their experiences and identities as 
Journal Committed to Social Change on Race and Ethnicity | Volume 5, Issue 2 | 2019

college students. First, for virtually all participants their engagement with

\#BlackGirlMagic did not begin until they came to college. While there were intricate differences between each of their stories, the participants shared a common experience related to hostile environments they faced. As a result of the hostility, they were forced to look for community and support that they could not find on campus. Saraphina offered that support for her as a Black woman is mostly lacking on her campus, and she sought support elsewhere:

It was something I realized I needed because I wasn't getting it anymore. And so, I guess I've been really lucky up until this point (prior to attending current institution) to get a lot of support and a lot of guidance, but, as a college student on the [institution] campus. I feel like for the most part that's absent. I have been seeking that and found that in my online community.

Multiple participants shared Saraphina's perspective and went on to say that so much of the success of Black women on college campuses is due to their own efforts and community building. Institutions thrive because Black women have taken on the burden and labor of supporting themselves and other Black women, which they felt was not something they should feel forced or obligated to do. Through their interviews these women conveyed an awareness of their own power and success. They achieved this through sharing statistics about successful graduation rates for Black women and the ways their digital and physical community have uplifted them. Lisa believes there is little her institution is doing toward achieving this success and that it is the labor of Black women at work:

Yeah. I don't really think that it has that much to do with the efforts that [institution] is making, but I would say more so the efforts of just us as a community and being in our organizations and uplifting each other and helping each other out that way. I would say that has more of an impact on anything that [institution] is trying to do. 
Journal Committed to Social Change on Race and Ethnicity | Volume 5, Issue 2 | 2019

In addition to the physical support they create for themselves on campus, participants also shared that online engagement facilitates further strengthening of the campus community. Participants indicate that engagement online through \#BlackGirlMagic, other hashtags related to Black women and other aspects of online Black women communities has allowed them to make connections on campus with other women, in ways the university should have supported. Trina shared,

I mean this university is huge, and so l've met folks who I had no idea went to school here through using hashtags on Twitter. And so, I think there is a sense that you know, in addition to having this digital community, here are folks that don't even know we exist in the same physical community.

Finally, multiple participants conveyed that although institutions repeatedly let them down through lack of support, they were committed to being successful anyway. They offered that institutions have thrived on the back and labor of Black women for a long time, but that should not be the reason they are not given the support they need.

Participants believed the lack of support they receive from their institution was related to the success they have matriculating through the institution and persisting to degree, which is also supported by other literature (Bond, 2011). Furthermore, they make distinctions between surviving and thriving, and they are committed to thriving despite the ways they are not supported. Alana recounts,

Had they given me more resources... that would have done it, I think I would have thrived a little bit more in the space. But I did what I had to do, like I said, I was going to thrive anyway... and I did it without them giving the resources, but what would have happened had they provided those resources to me?

\#BlackGirlMagic both online and in their physical manifestations on campus seem to be shouldering more of load of support to Black women, than the institutions where these women pay their money, time, and talents, which tends to be a costly bill indeed. 
Journal Committed to Social Change on Race and Ethnicity | Volume 5, Issue 2 | 2019

\section{Discussion and Implications}

While \#BlackGirlMagic was my point of departure to explore the ways that Black women on college campuses engage in everyday resistance through Twitter, participants in this study illuminate the complexity of identity and the ways resistance shows up for them in their daily lives online and offline. The stories that each of these women shared conveyed the importance of \#BlackGirlMagic while also more fully describing what \#BlackGirlMagic means to them; and, while Twitter is an integral piece, participants indicated that it was a tangential part of the experience. For these women, the hashtag transcends tweets, images and celebrations; \#BlackGirlMagic also included the communities of Black women where they found support for personal and academic issues. \#BlackGirlMagic for them was a way of thinking and being, a way to engage local community, to give back and pay-it-forward. These women are the literal manifestation of \#BlackGirlMagic and a form of resistance, and the resistance manifests simply because these women are, because they exist: they are resistance.

Black women's existence as resistance is a critical consideration because higher education scholars and administrators must ask the question, what exactly are they resisting against? According to these narratives, they resist against lack of support and full inclusion at the institution, they resist singular stories and flattened difference in the classroom, they resist standards of beauty thrust upon them, they resist policies, structures, histories, and legacies that mar higher education institutions. They resist having their needs and interests relegated to the wastelands of institutional priorities: they resist erasure and violence of all kinds. In this way, scholars and practitioners are tasked to admit and acknowledge that campus environments, by their natural being, are 
Journal Committed to Social Change on Race and Ethnicity | Volume 5, Issue 2 | 2019

not conducive to the success of Black women. However, despite the unwelcoming environment they name, these women often succeed without deserved help. The success of Black women should be an imperative for all institutions of higher education. According to their stories, much of their success had little to do with the efforts faculty and administrators create and provide resources to, and almost solely (particularly in the experiences of these women) due to their own efforts and labor.

The findings of this study are consistent with previous research that Black women garner the greatest support from themselves and other Black women (WinkleWagner, 2015), a reality that will require intentional interrogation to alleviate the undue burden. Institutional contexts vary greatly and I intentionally refrain from offering specific recommendations based on these women's experiences. However, a first step should include reaching out to Black women on campuses to ask them how the institution can be more supportive to them and then simply follow-through on their requests. In addition, participants shared ideas of what their campus could do to support their success and well-being:

- Institutional level recognition of their hard work and success.

- Successful faculty and student recruitment and retention initiatives.

- Institutionally organized opportunities to meet and network with other Black women across the institution and in the community.

- Earmarked financial support toward the personal, educational, and successful outcomes of Black women.

Finally, through these women's stories and experiences, this study has complicated the notion that activism and resistance are the same and that either should manifest in predetermined ways to be legitimate. This notion is strongly connected to and supported by Black feminist thought and articulations of Black women's activism 
Journal Committed to Social Change on Race and Ethnicity | Volume 5, Issue 2 | 2019

(Collins, 2002). There are two dimensions of Black women's activism one dimension more closely resembles traditional forms of activism. The first dimension more closely resembles how these participants discuss their own forms of resistance. Through Collins' discussion the first dimension is about creating spheres of influence where Black women can cultivate a free mind. These participants exhibited the same behavior: however, in addition to cultivating a free mind they sought to cultivate joy, peace, and community. They resisted toward cultivating a space, as much as they could, that was free from the pressures and pain of the world. Higher education scholars and educators must broaden how distress in students is recognized and understood on campus and in higher education communities. Students struggle and resist in different ways and as such campus marches, protests, sit-ins, or letter writing campaigns are but one way students might signal they are experiencing violence and trauma; however, that does not mean other students are not.

Higher education must push away from the adage "the squeaky wheel gets the oil," none of the wheels would ever have to "squeak" when they are properly supported and maintained. This study problematizes dominant perceptions and understandings of activism that renders certain types of resistance invisible or invaluable. These women all discuss the ways they carry resistance with them each day in classrooms, dining halls, research labs, and social spaces. What would it mean for campuses to become in-tune with the needs and experiences of Black women? Scholars and administrators should strive to understand these experiences so intimately that it would be obvious when their simple presence in place and space is causing them undue grief. 
Journal Committed to Social Change on Race and Ethnicity | Volume 5, Issue 2 | 2019

While activism can be a valuable tool toward liberation, there are certain privileges inherent in the way activism is enacted, who gets the choice to opt-in to it, and through it, whose labor gets recognized. Too often higher education environments have privileged certain activist issues and causes and thoroughly ignore and erase any efforts to champion a cause that does not engage traditional activist praxis. These findings suggest that there is a radical opportunity to zoom out on the landscape of collegiate institutions to understand despite the method of resistance (be it everyday resistance or a campus protest) that student intents are almost always the same. Students with minoritized identities want to feel affirmed and whole at their institutions, and these participants did not feel whole.

\section{Directions for Future Research}

Throughout the study participants shared powerful stories about their experiences and efforts to resist, persist, and thrive at institutions and through their online communities. In general, \#BlackGirlMagic was viewed as an empowering space and phenomenon in their lives. However, there were places within the data revealed a potential downside of \#BlackGirlMagic in their lives and through their experiences. Some participants shared feelings of expectation of perfection as it pertained to \#BlackGirlMagic in a way that did not allow them to be fully human, an expectation that did not allow them to be tired or broken. There was a concern that over time the expectation of what is recognized as \#BlackGirlMagic is limited to certain types of women, only certain types of physical looks and beauty, and only academic and career achievements. 
Journal Committed to Social Change on Race and Ethnicity | Volume 5, Issue 2 | 2019

Participants also critiqued \#BlackGirlMagic for the ways it only focused on celebrations, and they shared a desire for a place that fully acknowledged the ways they experience violence and trauma. One example cited was that \#BlackLivesMatter has/had come to be about Black men and as such there was a question about an equivalent focus around the societal plight of Black women. To be clear, these participants all identify and value \#BlackGirlMagic as a movement and a declaration: however, there were moments when they seemed to complicate certain aspects of how the hashtag is celebrated, specifically online. Future research should explore the complexity of \#BlackGirlMagic and how the pressures of perfection, beauty, success, and accomplishment affect Black women.

\section{Conclusion}

Activism, resistance, and social movements will continue to take up deserved space within the fabric of global society and within educational environments. Studies have repeatedly shown that higher education institutions reproduce the oppression reflected in the larger societal discourse (Linder et al., 2019), and in my view institutions have a long way to go to fully remedy and reify student concerns. More importantly, this study has revealed there are more issues to unpack and uncover as they pertain to minoritized students, what resistance is, and how resistant actions show up for them. Given that that institutions do not always rise to the appropriate level to support students who demonstrate on college campuses, institutions presumably do an even worse job when they are only able to recognize or understand traditional activist praxis. The Black women in this study were and continue to be magic, like so many other Black college students before them. However, in the words of Jesse Williams, "Just because 
Journal Committed to Social Change on Race and Ethnicity | Volume 5, Issue 2 | 2019

we're magic, doesn't mean we're not real." Higher education must make real changes to provide the space, support, and comfort that these real, though still magical, women deserve.

\section{References}

Barnett, B. M. (1993). Invisible Southern Black Women Leaders in the Civil Rights Movement: The Triple Constraints of Gender, Race, and Class. Gender \& Society, 7, (2), 162-182.

Bond, H., (2011). Black females in Higher Education at HBCU's: the Paradox of Success In Support Systems and Services for Diverse Populations: Considering the Intersection of Race, Gender, and the Needs of Black Female Undergraduates. Bingley, UK: Emerald Group Publishing Limited.

Brayboy, B. (2005). Toward a Tribal Critical Race Theory in Education. Urban Review, 37(5), 425-446.

Butz, D., \& Ripmeester, M. (1999). Finding Space for Resistant Subcultures. Invisible Culture.

Case, A. D., \& Hunter, C. D. (2012). Counterspaces: A Unit of Analysis for Understanding the Role of Settings in Marginalized Individuals' Adaptive Responses to Oppression. American Journal of Community Psychology.

Collins, P. H. (1990). Knowledge, Consciousness, and the Politics of Empowerment. Black Feminist Thought, 21(1), 132-133.

Collins, P. H. (2002). Black feminist thought. [electronic resource]: knowledge, consciousness, and the politics of empowerment. New York: Routledge, 2002.

Dames, S. (2018) Impact of interplaying and compounding factors in the novice nurse journey: A basic qualitative research study. Canadian Journal of Nursing Research, 1-10. https://doi.org/10.1177\%2F0844562118817079 
Journal Committed to Social Change on Race and Ethnicity | Volume 5, Issue 2 | 2019

Delgado, R., \& Stefancic, J. (2012). Critical Race Theory: An Introduction. Race (2nd ed.). New York, NY: New York University Press.

Dillard, C. B. (2006). The substance of things hoped for, the evidence of things not seen: Examining an endarkened feminist epistemology in educational research and leadership. In, SUNY series in Women in Education (p. 1). Albany: State University of New York Press.

Dillard, C., B., (2008). When the ground is black, the ground is fertile: exploring endarkened feminist epistemology and healing methodologies in the spirit. In Denzin, N. K., Lincoln, Y. S. \& Smith, L. T. Handbook of critical and indigenous methodologies (pp. 277-292). Thousand Oaks, CA: SAGE.

Domingue, A. D. (2015). "Our leaders are just we ourself': Black women college student leaders' experiences with oppression and sources of nourishment on a predominantly white college campus. Equity \& Excellence in Education, 48(3), 454-472. http://doi.org/10.1080/10665684.2015.1056713

Glenn, C. L. (2015). Activism or "Slacktivism?": Digital Media and Organizing for Social Change. Communication Teacher, 29(2), 81-85.

Goodman, N., \& Light, D., (2016) Coding twitter: Lessons from a content analysis of informal science, presented at the American Educational Research Association Annual Meeting, San Antonio, TX. Retrieved from: http://cct.edc.org/sites/cct.edc.org/files/publications/AERA2016_TwISLE.pdf Howard-Hamilton, M. F., (2003) Theoretical frameworks for African American women. New Directions for Student Services 104, 19-27

Jaschik, S. (2016, July 11). Students, colleges and academic groups respond to a week of tragedies. Inside HigherEd Retrieved from https://www.insidehighered.com/news/2016/07/11/students-colleges-andacademic-groups-respond-week-tragedies

Johansson, A., \& Vinthagen, S. (2016). Dimensions of Everyday Resistance: An Analytical Framework. Critical Sociology (Sage Publications, Ltd.), 42(3), 417435. 
Journal Committed to Social Change on Race and Ethnicity | Volume 5, Issue 2 | 2019

Linder, C., Quaye, S. J., Stewart, T. J., Okello, W. K., \& Roberts, R. E. (2019). The whole weight of the world on my shoulders: power, identity, and student activism. Journal of College Student Development, 60(5), 527-542.

Merriam, S. B. (2002). Qualitative research in practice: examples for discussion and analysis. San Francisco: Jossey-Bass.

Merriam, S. B. (2009) Qualitative research: A guide to design and implementation. San Francisco, CA: Jossey-Bass.

Saldaña, J. (2009). The coding manual for qualitative research. Thousand Oaks, CA: Sage

Scott, J. C. (1990). Domination and the arts of resistance: hidden transcripts. Book, New Haven: Yale University Press, c1990.

Stewart, T. J., \& Williams, B. M. (2019) Nuanced activism: The matrix of resistance. In A. Dache-Gerbino, S. J. Quaye, C. Linder, \& K. McGuire (Eds.), Rise up!: Activism as Education. East Lansing, MI: Michigan State University Press.

@thepbg. (2017, April 30). That's enough, miss shawn. Retrieved from: https://twitter.com/thepbg

Towns, A. R. (2016). Geographies of Pain: \#SayHerName and the Fear of Black Women's Mobility. Women's Studies in Communication, 39(2), 122-126.

Williams, S. (2015). Digital Defense: Black Feminists Resist Violence with Hashtag Activism. Feminist Media Studies, 15(2), 341-344.

Winkle-Wagner, R. (2015). Having Their Lives Narrowed Down? The State of Black Women's College Success. Review of Educational Research, 85(2), 171-204.

Yang, G. (2016). Narrative Agency in Hashtag Activism: The Case of \#BlackLivesMatter. Media \& Communication, 4(4), 13-17. doi:10.17645/mac.v4i4.692 